\title{
PENGARUH ONLINE FLOW ELEMENTS DAN KEPUASAN PADA PENGALAMAN BELANJA HEDONIS DAN UTILITARIAN: STUDI KASUS PADA SOCIAL COMMERCE
}

\author{
Lukluk Atul Hidayati \\ Anissa Hakim Purwantini \\ Universitas Muhammadiyah Magelang \\ anissa.hakim@ummgl.ac.id
}

\begin{abstract}
This study examined the relationship between online flow elements on hedonic and utilitarian online shopping experience and its influence on the satisfaction that later influenced the social commerce intention. The research sample using purposive sampling method of social media users who ever search information and purchase online through social media as Facebook, Instagram, Twitter or Path. The results of this study indicate that arousal, challenge and time distortion have positive effect on hedonic online shopping experience, whereas telepresence haven't significant effect. Importance, interactivity and skill positively influence utilitarian online shopping experience, while the control has no effect. Utilitarian shopping experience influence satisfaction, whereas no significant effect on hedonic shopping experience. Satisfaction positively influence repurchase intention in social commerce.
\end{abstract}

Keywords: online flow elements, hedonic, utilitarian, satisfaction, social sommerce

\section{PENDAHULUAN}

Peningkatan pengguna internet di dunia memudahkan para pebisnis untuk memasarkandan mengembangkan lahan bisnisnya (Al Kasasbeh et al., 2011). Data yang diambil pada bulan Oktober 2016 menunjukkan jumlah pengguna aktif internet di Indonesia mencapai 132,7 juta orang (Widiartanto, 2016) dan pengguna media sosial meningkat sebesar 19\% dengan jumlah sekitar lebih dari 74 juta orang (Kemp, 2015). Pengguna internet tersebut merupakan konsumen potensial untuk bisnis online (Zhang et al., 2009).

Peningkatan popularitas media sosial sebagai alat komunikasi dan berbagi informasi menjadikan sebuah bentuk baru dari e-commerce yang disebut dengan social commerce (Liang etal., 2011). Menurut Liang dan Turban (2011) social commerce merupakan bagian dari e-commerce yang melibatkan penggunaan media sosial untuk membantu transaksi dan aktivitas e-commerce. Sebuah situs web social commerce merupakan tempat di mana individu dapat berkolaborasi secara online, mendapatkan saran dari orang yang terpercaya terkait produk, menemukan barang yang diinginkan dan kemudian membelinya.

Perkembangan social commerce mendorong pentingnya untuk memahami perilaku konsumen online. Straub dan Watson (2001) menyatakan bahwa perlu untuk memahami dan 
mengukur perilaku konsumen online, terutama pada bidang sistem informasi. Literatur terdahulu telah banyak yang mengkaji perilaku konsumen online, namun banyak penelitian yang belum dapat menjelaskan kompetensi dari website online shopping yang mendorong perilaku pembelian online secara aktual (Smith dan Sivakumar, 2004). Menurut Lim (2013), konsumen yang tertarik dengan iklan yang dipasang di website dan sering mengunjungi website untuk berkomunikasi tetapi tidak melakukan pembelian, dimungkinkan karena mereka tidak mendapatkan pengalaman berbelanja online. Belum banyak riset empiris yang meneliti faktor-faktor yang mendorong pengalaman pada website online shopping (Hoffman dan Novak, 2009).

Lim (2014) melakukan penelitian untuk menguji respon konsumen terhadap karakteristik website berdasarkan pada theory offlow (Hoffman dan Novak, 1996). Penelitian Lim (2014) mengintegrasikan dua aliran riset yaitu: perspektif sistem informasi dengan online interface dari sistem informasi komputerisasi, dan perspektif pemasaran mengenai perilaku konsumen online. Theory of online flow digunakan sebagai landasan teoritis untuk memahami elemen yang terdapat pada online interface yang memfasilitasi flow. Pengalaman belanja online yang digunakan yaitu hedonic dan utilitarian.

Penelitian ini mendasarkan pada model yang digunakan Lim (2014) yang menguji elemen di dalam online interface dari sistem informasi terkomputerisasi yang memfasilitasi online flow serta hubungannya dalam menciptakan pengalamanhedonis danutilitarian padakonsumen di dalam konteks Online Group Buying (OGB) website. Perbedaan penelitian ini yaitu pertama, menambahkan variabel satisfaction, sehingga dapat memperjelas model Lim (2014). Penelitian Sagala dan Sumiyana (2014) menunjukkan bahwa nilai-nilai hedonis dan utilitarian dapat memengaruhi kepuasan konsumen, sehingga mendorong untuk melakukan pembelian online. Perbedaan kedua, penelitian ini menggunakan konteks yang berbeda, Lim (2014) menggunakan Online Group Buying sedangkan penelitian ini menggunakan social commerce dengan platform media sosial Facebook, Instagram, Twitter dan Path. Penggunaan konteks social commerce ini sesuai dengan saran dari Lim (2014) yang menyatakan bahwa:

“...tidak dapat diyakinkan apakah terdapat perbedaan signifikan di dalam hubungan antara online flow elements, pengalaman belanja online, dan niat perilaku pada bentuk e-commerce yang berbeda. Penelitian selanjutnya diharapkan menguji hubungan tersebut dengan platform e-commerce lainnya." (hal. 300).

Penelitian ini bertujuan menguji sebuah model respon dari konsumen terhadap karakterisitik websites media sosial berdasarkan pada theory of flow pada pengalaman belanja online hedonis dan utilitarian. Lebih lanjut, penelitian ini mengkaji dampak theory of flow pada pengalaman belanja online hedonis dan utilitarian terhadap kepuasan yang selanjutnya akan berpengaruh pada niat membeli kembali dalam konteks social commerce.

Kesuksesan bisnis online yang menggunakan media sosial sebagai tempat jualbeli ditentukan oleh adanya kontinuitas pembelian konsumen. Karakteristik teknologi media sosial yang mampu menciptakan pengalaman belanja konsumen akan menciptakan kepuasan yang selanjutnya menggerakkan konsumen untuk membeli kembali. Penelitian ini penting karena bukti empiris terkait pengaruh human-computer interface terhadap perilaku pembelian konsumen pada konteks media sosial belum banyak diteliti (Zhang et al., 2014), sehingga peneliti tertarik untuk mengkaji lebih lanjut. 


\section{REVIEW LITERATUR DAN HIPOTESIS}

\section{Theory of Online Flow}

Csikszentmihalyi (1975) dalam Lim (2014) mendefinisikan flow sebagai kondisi di mana seseorang terlibat secara optimal dalam suatu aktivitas yang menimbulkan pengalaman menyenangkan meskipun harus mengeluarkan biaya yang besar untuk melakukannya. Sementara itu, Nah et al., (2011) menjelaskan flow sebagai keadaan pengalaman optimal ketika individu merasakan keterlenaan (absorp) dan terlibat dalam aktivitas yang membawa dirinya seolah-olah tidak memiliki masalah. Berdasarkan Csikszentmihalyi (1975, 1997), Hoffman dan Novak (1996) memberikan konsep terkait flow dalam konteks internet, yaitu online flow merupakan kondisi yang terjadi selama navigasi jaringan yang ditandai: (1) urutan tanggapan respon yang difasilitasi oleh interaktivitas mesin, (2) kesenangan secara intrinsik, (3) disertai dengan hilangnya kesadaran diri, (4) "selfreinforcing."

Terdapat perbedaan pengukuran konstruk online flow pada literatur terdahulu. Hal ini disebabkan oleh beragamnya konseptualisasi, operasionalisasi dan pengukuran dari online flow. Riset ini menggunakan konsep Hoffman dan Novak (2009) dengan menggunakan pengukuran multidimensional dari flow yang mengatasi kelemahan pada pengukuran unidimensional.

\section{Pengalaman Berbelanja}

Wolfinbarger dan Gilly (2001) mengemukakan bahwa konsumen melakukan belanja online untuk tujuan hedonis dan utilitarian. Hedonic didefinisikan sebagai keterbukaan terhadap pengalaman yang menyenangkan, di mana kesenangan (pleasure) (termasuk enjoyment dan delight) adalah satu-satunya tujuan dalam hidup (O'Shaghnessy dan O'Shaghnessy, 2002; Venhooven, 2003; Sledgianowski dan Kulviwatt,
2009). Sebaliknya, Okada (2005) mendefinisikan utilitarian sebagai tindakan yang memaksimalkan utilitas atau kegunaan.

Scarpi (2012) memberikan penyatuan konseptualisasi dari kedua konsep hedonic dan utilitarian di dalam konteks shopping environment yaitu "hedonic merupakan kondisi yang lebih berpengaruh dengan kesenangan dan kegembiraan dibandingkan dengan penyelesaian tugas, sehingga mencerminkan sisi pengalaman yang menyenangkan dari berbelanja, keingintahuan, khayalan, escapism (pelarian dari kenyataan), dan kesenangan. Sedangkan utilitarian berpengaruh dengan sebuah pengalaman yang memfasilitasi pencapaian dari sesuatu yang penting dibandingkan dengan hanya untuk kesenangan. Menurut Bridge dan Florsheim (2008), konsumen online mendapatkan pengalaman hedonis melalui rangsangan/arousal, playfulness, dan pengaruh positif. Sedangkan pengalaman utilitarian melalui kenyamanan, akses yang bagus, adanya pilihan dan ketersediaan informasi.

Childers et al., (2001) melakukan penelitian dengan mengintegrasikan karakteristik hedonis dan utilitarian dalam menjelaskan perilaku pembelian konsumen pada perdagangan online. Karakteristik hedonis digambarkan dengan kenikmatan persepsian dan kemudahan penggunaan persepsian, sedangkan karakteristik utilitarian digambarkan dengan kebermanfaatan persepsian.

\section{Pengembangan Hipotesis}

\section{Online Flow Elements}

Penelitian O'Shaghnessy dan O'Shaghnessy (2002) menunjukkan bahwa konsumen yang mencari pengalaman hedonis dapat mendapatkannya melalui fantasy, escape, arousal dan pleasure. Menurut Bridges dan Florsheim (2008), konsumen yang mencari pengalaman utilitarian kemungkinan akan mendapatkan pengalaman tersebut melalui 
elemen flow seperti tingkat ketrampilan online, kontrol, dan kecepatan website persepsian.

Penelitian ini menggunakan unsur-unsur online flow (anteseden) yang didefinisikan oleh Novak, Hoffman, dan Yung (2000) sebagai premis untuk pengembangan hipotesis. Online flow terdiri dari: arousal adalah ukuran dari rangsangan; tantangan yang menunjukkan kemampuan seseorang terkait skill; telepresence menunjukkan perasaan kehadiran di ' dunia yang berbeda" dan distorsi waktu yang menunjukkan waktu akan dengan cepat berlalu tanpa disadari ketika berinteraksi dengan informasi sistem komputer. Selanjutnya, kontrol berarti bahwa pengguna memahami sistem informasi komputer dan mengetahui apa yang harus dilakukan, pentingnya menunjukkan peran sistem informasi komputer dalam kehidupan pengguna, interaktivitas menangkap persepsi kecepatan online, dan keterampilan mencerminkan penilaian diri pengetahuan tentang sistem informasi komputer.

\section{Anteseden dari Pengalamana Belanja Online Hedonis}

Literatur terdahulu menunjukkan bahwa tingkat perceived arousal dan challenge di dalam interkasi individu-komputer berpengaruh positif terhadap pencapaian flow (Ghani dan Deshpdane, 1994). Penelitian Smith dan Sivakumar (2004) menunjukkan bahwa keterlibatan dalam pengalaman yang mendebarkan dan menarik merupakan motivasi diri sendiri, karena keterlibatan tersebut memfasilitasi perasaan senang. Literatur terdahulu (Fiore, Jin, dan Kim 2005; Shih 1998) menemukan bukti empiris bahwa perasaan kehadiran di toko virtual yang mirip dalam kualitas dan kuantitas, dalam hal informasi sensorik simulasi produk brick dan mortar store menciptakan pengalaman yang sangat memuaskan konsumen online. Menurut Bridges dan Florsheim (2008), adanya pengalaman menyebabkan konsumen online menghabiskan waktu dalam penggunaan Internet tanpa memerhatikan berapa banyak waktu yang telah berlalu. Temuan empiris Lim (2014) menemukan bukti empiris hubungan positif antara arousal, challenge, dan distortion terhadap pengalaman belanja hedonis. Maka hipotesis yang dirumuskan adalah:

$\mathrm{H}_{1}$ : Arousal berpengaruh positif terhadap pengalaman berbelanja online hedonic.

$\mathrm{H}_{2}$ : Challenge berpengaruh positif terhadap pengalaman berbelanja online hedonic.

$\mathrm{H}_{3}$ : Telepresence berpengaruh positif terhadap pengalaman berbelanja online hedonic.

$\mathrm{H}_{4}$ : Time distortion berpengaruh positif terhadap pengalaman berbelanja online hedonic.

\section{Anteseden dari Pengalamana Belanja Online Utilitarian}

Literatur terdahulu telah menitikberatkan sebuah hubungan antara utilitarianisme dan tingkat kontrol yang tinggi, importance, interactivity, dan skill (ketrampilan) ketika melakukan aktivitas online. Penelitian Ward dan Barnes (2001) menemukan bukti empiris bahwa pengguna yang mempersepsikan tingkat kontrol yang lebih tinggi ketika berbelanja dalam toko online akan meningkatkan kinerja berbelanja (menyimpan waktu berbelanja dan menemukan kesepakatan terbaik) dan memfasilitasi dalam pencapaian tujuan berbelanja yaitu menemukan barang yang dibutuhkan. Kontrol dari persepsi pengguna di dalam sistem informasi komputer merupakan hal yang penting karena dapat memfasilitasi sebuah pengalaman berbelanja online utilitarian melalui pemberian kemudahan dalam pencapaian tujuan belanja (Dailey, 2004).

Lau (2012) menyatakan dapat diduga bahwa konsumen mungkin akan merasakan keuntungan dari pengalaman berbelanja utilitarian dari website media sosial ketika situs tersebut dapat memaksimalkan pemenuhan nilai seperti dapat menghemat waktu dan uang. Menurut 
Richard dan Chandra (2005), menyatakan bahwa semakin besar kecepatan respon (interactivity) antara konsumen dengan situs, maka konsumen akan lebih mempertimbangkan kegunaan dari situs tersebut. Ketrampilan yang dimiliki konsumen dapat meningkatkan kinerja tugas (Shank, 2011). Hasil penelitian Lim (2014) menemukan bahwa control, interactivity, dan skill memiliki pengaruh postif terhadap pengalaman belanja online utilitarian.

Maka hipotesis yang dirumuskan adalah:

$\mathrm{H}_{5}$ : Control berpengaruh positif terhadap pengalaman berbelanja online utilitarian.

$\mathrm{H}_{6}$ : Importance berpengaruh positif terhadap pengalaman berbelanja online utilitarian.

$\mathrm{H}_{7}$ : Interactivity(speed) berpengaruh positif terhadap pengalaman berbelanja online utilitarian.

$\mathrm{H}_{8}$ : Skill berpengaruh positif terhadap pengalaman berbelanja online utilitarian.

\section{Pengalaman Belanja Online, Kepuasan dan Niat Membeli Kembali}

Menurut Heijden (2004), nilai dari sistem hedonis merupakan fungsi dari seberapa besar pengalaman pengguna akan menyenangkan ketika menggunakan sebuah sistem. Individu yang merasakan bahwa media sosial memungkinkan mereka untuk "melarikan diri" dari dunia nyata, mereka akan lebih mengalami keterlenaan terhadap media sosial (Holsapple dan Wu, 2007). Adanya pengalaman belanja hedonic akan memunculkan rasa senang yang merangsang individu untuk bertahan dalam situasi senang tersebut. Hedonic yang dibentuk dari adanya respon emosional (arousal, pleasure dan dominance) akan membangun persepsi manfaat dari situs yang digunakan (Wang dan Scheepers, 2012). Berbagai perasaan senang yang dialami oleh konsumen online ketika menggunakan media sosial akan membangun kepuasan di dalam dirinya karena terpenuhinya persepsi manfaat dari media sosial.

Nilai persepsian merupakan manifestasi dari nilai utilitarian. Penelitian Wang (2007) menunjukkan bahwa nilai persepsian mengacu pada biaya dan manfaat yang ditimbulkan oleh pengguna sistem informasi perdagangan elektronik yang akan menstimuli rasa pantas atau beruntung bagi pengguna. Kepuasan mengacu pada perasaan yang menguntungkan bagi konsumen terhadap suatu layanan tertentu (Kim dan Son, 2009; Zhou et al., 2012). Berdasarkan argumen tersebut, konsumen online yang memiliki pengalaman utilitarian akan merasakan manfaat dari sistem yang ada di media sosial, sehingga akan membentuk kepuasan.

Perasaan puas yang didapat dari kecocokan sistem teknologi yang digunakan dalam belanja online akan mendorong konsumen untuk membeli kembali. Kepuasan konsumen merupakan kunci untuk menghubungkan nilai persepsian yang diwakili oleh utilitarianism dan pengalaman flow (hedonism) terhadap niat untuk membeli kembali di social commerce. Hasil penelitian (Sagala dan Sumiyana, 2014) menemukan bukti empiris hubungan positif antara kepuasan dan niat membeli kembali pada online store di facebook. Berdasarkan argumen dan penelitian terdahulu maka hipotesis yang dirumuskan adalah:

$\mathrm{H}_{9}$ : Pengalaman belanja online hedonic berpengaruh positif tehadap kepuasan.

$\mathrm{H}_{10}$ : Pengalaman belanja online utilitarian berpengaruh positif tehadap kepuasan.

$\mathrm{H}_{11}$ : Kepuasan berpengaruh positif terhadap niat untuk membeli kembali di social commerce. 


\section{METODE PENELITIAN}

\section{Populasi dan Sampel Penelitian}

Populasi merupakan kumpulan dari keseluruhan elemen di mana kita akan menarik beberapa kesimpulan (Cooper dan Schindler, 2006). Populasi dalam penelitian ini adalah pengguna media sosial dalam hal ini adalah Facebook, Instagram, Twitter dan Path. Sampel penelitian yaitu pengguna keempat media sosial tersebut yang pernah melakukan belanja online. Teknik pengambilan sampel dilakukan dengan purposive sampling, yaitu pengambilan sampel berdasarkan pada kriteria tertentu. Kriteria yang digunakan yaitu:

1. Pernah melakukan pencarian informasi terkait dengan barang yang diperjualbelikan di media sosial (Facebook, Instagram, Twitter dan Path).

2. Pernah melakukan pembelian online melalui media sosial tersebut.

\section{Pengukuran Variabel}

Item-item pengukuran variabel dalam penelitian ini diadopsi dari penelitian sebelumnya. Semua variabel dalam penelitian ini dikur menggunakan skala Likert 7 poin dengan rentang nilai antara 1 (sangat tidak setuju) sampai dengan 7 (sangat setuju). Definisi operasional dan pengukuran masing-masing variabel dijabarkan dalam tabel berikut:
Tabel 1

Definisi Operasional Variabel

\begin{tabular}{|c|c|c|c|}
\hline Konstruk & Definisi operasional & Pertanyaan & Referensi \\
\hline Arousal & $\begin{array}{l}\text { Stimulus dari sistem teknologi di } \\
\text { media sosial yang menarik konsumen } \\
\text { ketika melakukan belanja online. }\end{array}$ & 4 & $\begin{array}{l}\text { Koufaris(2002), McQuarrie dan } \\
\text { Munson (1992), dan Novak et } \\
\text { al., (1998) }\end{array}$ \\
\hline Challenge & $\begin{array}{l}\text { Perasaan yang menantang } \\
\text { kemampuan konsumen untuk } \\
\text { menggunakan skill ketika berbelanja } \\
\text { online. }\end{array}$ & 4 & $\begin{array}{l}\text { Koufaris (2002), Novak et } \\
\text { al., (1998) dan Richard dan } \\
\text { Chandra(2005) }\end{array}$ \\
\hline Telepresence & $\begin{array}{l}\text { Perasaan seperti telah hadir dalam } \\
\text { "dunia yang lain" ketika berbelanja } \\
\text { online. }\end{array}$ & 4 & Lee dan Chen (2010) \\
\hline Time Distortion & $\begin{array}{l}\text { Waktu berlalu dengan cepat ketika } \\
\text { berinteraksi dengan media sosial } \\
\text { dalam belanja online. }\end{array}$ & 3 & Lee dan Chen (2010) \\
\hline Control & $\begin{array}{l}\text { Konsumen mampu mengoperasikan } \\
\text { fitur-fitur yang ada di media sosial } \\
\text { ketika berbelanja online. }\end{array}$ & 4 & $\begin{array}{l}\text { Koufaris (2002), Novak } \text { et al., } \\
\text { (1998), dan Lee dan Chen (2010) }\end{array}$ \\
\hline Importance & $\begin{array}{l}\text { Peran dari media sosial di dalam } \\
\text { kehidupan konsumen. }\end{array}$ & 4 & $\begin{array}{l}\text { McQuarrie dan Munson (1992), } \\
\text { Richard dan Chandra (2005) }\end{array}$ \\
\hline $\begin{array}{l}\text { Interactivity } \\
\text { (Speed) }\end{array}$ & $\begin{array}{l}\text { Persepsi dari konsumen mengenai } \\
\text { kecepatan respon dari situs media } \\
\text { sosial ketika melakukan belanja } \\
\text { online. }\end{array}$ & 3 & Richard dan Chandra (2005) \\
\hline Skill & $\begin{array}{l}\text { Penilaian diri sendiri oleh konsumen } \\
\text { mengenai pengetahuan terkait media } \\
\text { sosial. }\end{array}$ & 4 & $\begin{array}{l}\text { Koufaris (2002), Novak et al., } \\
\text { (1998), dan Richard dan Chandra } \\
\text { (2005) }\end{array}$ \\
\hline Hedonism & $\begin{array}{l}\text { Pengalaman konsumen yang menarik, } \\
\text { menyenangkan, dan merasakan } \\
\text { petualangan ketika melakukan belanja } \\
\text { online melalui media sosial. }\end{array}$ & 3 & $\begin{array}{l}\text { Babin et al. (1994), Bridges dan } \\
\text { Florsheim (2008), Gupta dan Kim } \\
\text { (2009), dan Jones et al., (2006) }\end{array}$ \\
\hline Utilitarianism & $\begin{array}{l}\text { Pengalaman konsumen yang } \\
\text { mencerminkan terpenuhinya tujuan } \\
\text { berbelanja seperti menemukan barang } \\
\text { yang dicari dan kesesuaian harga. }\end{array}$ & 3 & $\begin{array}{l}\text { Babin } \text { et al.,(1994), Bridges dan } \\
\text { Florsheim (2008), Gupta dan Kim } \\
\text { (2009), dan Jones et al., (2006) }\end{array}$ \\
\hline Satisfaction & $\begin{array}{l}\text { Perasaan puas terhadap layanan } \\
\text { konsumen yang didapatkan dari } \\
\text { penggunaan media sosial ketika } \\
\text { melakukan belanja online. }\end{array}$ & 3 & Wang (2007) \\
\hline Intention & $\begin{array}{l}\text { Niat konsumen untuk membeli } \\
\text { kembali melalui media sosial. }\end{array}$ & 3 & $\begin{array}{l}\text { Jones et al. (2006) dan Lim dan } \\
\text { Ting (2012a, 2012b) }\end{array}$ \\
\hline
\end{tabular}

\section{Jenis dan Sumber Data}

Sumber data yang digunakan dalam penelitian ini adalah data primer, yaitu data yang diambil langsung dari sumbernya. Data primer mengacu pada informasi yang diperoleh dari tangan pertama yang dilakukan peneliti terkait dengan variabel penelitian untuk tujuan studi spesifik (Sekaran, 2006). Data diperoleh dengan menggunakan kuesioner yang diisi oleh responden dengan teknik pengumpulan data survei langsung. Kuesioner yang telah diisi 
oleh responden, diseleksi terlebih dahulu agar kuesioner yang tidak lengkap pengisiannya tidak disertakan dalam analisis. Peneliti memilih cara demikian dengan pertimbangan bahwa metode survei langsung lebih efektif dan mengurangi risiko tidak kembalinya kuesioner yang telah disebar.

\section{Metode Analisis Data}

\section{Uji Validitas dan Reliabilitas}

Pengujian validitas terdiri dari dua yaitu convergent validity dan discriminant validity. Convergent validity digunakan untuk menilai seberapa besar korelasi antara dua ukuran dari konsep yang sama. Pengukuran convergent validity dihitung dengan nilai Average Variance Extracted(AVE)yaitujumlahkuadratstdanardized factor dibagi dengan jumlah item pengukuran. Rule of thumb dari nilai AVE yaitu lebih tinggi dari 0.5 (Hair dkk, 2010). Dicriminant validity merupakan penilaian seberapa berbeda suatu konstruk dengan konstruk lainnya, yaitu diukur dengan membandingkan nilai AVE dari kedua konstruk dengan nilai kuadrat korelasi antara dua konstruk yang diuji tersebut. Discriminant validity yang baik jika nilai AVE lebih tinggi dari nilai kuadrat korelasi antar konstruk (Hair et al., 2010). Pengujian reliabilitas dilakukan dengan pengukuran yang memenuhi kriteria nilai cronbach alpha dan composite reliability di atas 0,7 meskipun 0,6 masih dapat diterima (Hair et al., 2010). Semakin besar nilai cronbach's alpha maka semkin tinggi tingkat reliabilitas alat ukur yang digunakan.

\section{Uji Model dan Uji Hipotesis}

Penelitian ini menggunakan SEM-PLS dengan Visual Partial Least Square (VPLS) sebagai alat analisis untuk menguji model dan hipotesis. Model struktural dalam PLS dievaluasi menggunakan $\mathrm{R}^{2}$ untuk konstruk dependen, sedangkan pengujian signifikansi antar konstruk menggunakan nilai koefisien path atau t-values setiap path. Nilai $\mathrm{R}^{2}$ mencerminkan tingkat variasi perubahan variabel independen terhadap variabel dependen. Nilai $\mathrm{R}^{2}$ yang semakin tinggi menunjukkan model prediksi penelitian yang diajukan semakin baik, namun parameter utamanya adalah dasar hubungan teoritikal (Hartono, 2009).

Tingkat signifikansi dalam pengujian hipotesis ditunjukkan oleh nilai koefisien path (inner model). Rule of thumb skor koefisien yang ditunjukkan oleh nilai $t$-statistic harus di atas 1.96 untuk hipotesis two tailed dan di atas 1,64 untuk hipotesis one tailed pada pengujian hipotesis dengan menggunakan alpha $5 \%$ dan power $80 \%$ (Hair et al., 2010).

\section{HASIL PENELITIAN DAN PEMBAHASAN}

\section{Deskripsi Objek Penelitian}

Kuesioner yang berhasil dikumpulkan berjumlah 155 responden. Akan tetapi hanya 138 responden yang dapat diolah, sehingga persentase jumlah kuesioner yang dapat digunakan untuk penelitian sebesar $89,03 \%$. 
Tabel 2

\section{Karakteristik Responden}

\begin{tabular}{|c|c|c|c|c|}
\hline No & \multicolumn{2}{|c|}{ Karakteristik Responden } & \multicolumn{2}{|c|}{ Jumlah } \\
\hline \multirow[t]{2}{*}{1} & \multirow[t]{2}{*}{ Jenis Kelamin } & Laki-laki & 44 & $32 \%$ \\
\hline & & Perempuan & 94 & $68 \%$ \\
\hline \multirow[t]{5}{*}{2} & \multirow[t]{5}{*}{ Usia } & 16-20 tahun & 39 & $28 \%$ \\
\hline & & 21-25 tahun & 85 & $62 \%$ \\
\hline & & 26-30 tahun & 8 & $6 \%$ \\
\hline & & 31-35 tahun & 3 & $2 \%$ \\
\hline & & diatas 35 tahun & 3 & $2 \%$ \\
\hline \multirow[t]{4}{*}{3} & \multirow[t]{4}{*}{ Pendidikan } & $\begin{array}{l}\text { Sekolah Menengah Atas } \\
(\mathrm{SMA} / \mathrm{K})\end{array}$ & 120 & $87 \%$ \\
\hline & & Diploma (D3) & 13 & $9 \%$ \\
\hline & & Sarjana (S1) & 2 & $2 \%$ \\
\hline & & Pasca Sarjana (S2) & 3 & $3 \%$ \\
\hline \multirow[t]{6}{*}{4} & \multirow[t]{6}{*}{ Pekerjaan } & Mahasiswa & 55 & $40 \%$ \\
\hline & & Wirausaha & 17 & $12 \%$ \\
\hline & & PNS & 3 & $2 \%$ \\
\hline & & Karyawan & 58 & $42 \%$ \\
\hline & & Profesional & 3 & $2 \%$ \\
\hline & & Lainnya & 2 & $2 \%$ \\
\hline \multirow[t]{3}{*}{5} & \multirow{3}{*}{$\begin{array}{l}\text { Frekuensi } \\
\text { belanja online } \\
\text { dalam } 3 \text { bulan } \\
\text { terakhir }\end{array}$} & 1-2 kali & 61 & $44 \%$ \\
\hline & & 3-4 kali & 31 & $23 \%$ \\
\hline & & lebih dari 4 kali & 46 & $33 \%$ \\
\hline \multirow[t]{4}{*}{6} & \multirow{4}{*}{$\begin{array}{l}\text { Mulai } \\
\text { berbelanja } \\
\text { online }\end{array}$} & Kurang dari 6 bulan & 29 & $21 \%$ \\
\hline & & 6-12 bulan & 23 & $17 \%$ \\
\hline & & 1-2 tahun & 46 & $33 \%$ \\
\hline & & lebih dari 2 tahun & 40 & $29 \%$ \\
\hline \multirow[t]{5}{*}{7} & \multirow{5}{*}{$\begin{array}{l}\text { Penghasilan } \\
\text { per bulan }\end{array}$} & Rp500.000-Rp1.000.000 & 59 & $43 \%$ \\
\hline & & Rp1.000.000-Rp1.500.000 & 30 & $22 \%$ \\
\hline & & Rp1.500.000-Rp2.000.000 & 27 & $20 \%$ \\
\hline & & Rp2.000.000-Rp2.500.000 & 11 & $8 \%$ \\
\hline & & Lainnya & 11 & $8 \%$ \\
\hline \multirow[t]{4}{*}{8} & \multirow{4}{*}{$\begin{array}{l}\text { Media sosial } \\
\text { terpopuler } \\
\text { untuk belanja } \\
\text { online }\end{array}$} & Facebook & 68 & $49 \%$ \\
\hline & & Instagram & 65 & $47 \%$ \\
\hline & & Twitter & 2 & $2 \%$ \\
\hline & & Path & 3 & $2 \%$ \\
\hline
\end{tabular}

Berdasarkan tabel karakteristik responden, dapat diketahui bahwa berdasarkan jenis kelamin, responden perempuan lebih banyak daripada responden laki-laki, yaitu sebanyak 94 orang atau sebesar 68,1\%. Dilihat dari usia, pendidikan, dan latar belakang pekerjaan responden, rata-rata pengguna media sosial yang pernah berbelanja online dan berniat melakukan transaksi pembelian kembali melalui media sosial adalah kalangan usia muda dengan rentang usia antara 21 sampai dengan 25 tahun dengan tingkat pendidikan terakhir sebagian besar SMA dan berstatus sebagai mahasiswa serta sebagian telah bekerja. Responden paling banyak melakukan pembelian online dengan frekuensi 1-2 kali dalam tiga bulan terkahir. Tingkat pendapatan antara Rp500.000,00 sampai dengan Rp1.000.000,00 $(43 \%)$ serta memulai berbelanja online melalui media sosial sejak 1-2 tahun yang lalu.

\section{Hasil Uji Validitas dan Reliabilitas Data}

Uji validitas dalam penelitian ini menggunakan analisis faktor konfirmatori. Nilai KMO 0,791 dan signifikansi yang dihasilkan dari Bartlett's Test of Sphericity sebesar 0,000. Hasil menunjukkan nilai $>0,5$ sehingga dapat dikatakan bahwa variabel dan sampel yang digunakan memungkinkan untuk dilakukan analisis lebih lanjut. Uji validitas konvergen dan diskriminan semua terpenuhi dengan menghilangkan beberapa item pertanyaan yang tidak valid (control, hedonic, time distortion, skill). Hasil pengujian validitas menunjukkan keseluruhan item pernyataan di semua variabel penelitian memiliki nilai faktor loading di atas 0,5. Hal tersebut berarti seluruh item pertanyaan variabel valid. Pengujian reliabilitas menunjukkan keseluruhan konstruk memiliki nilai composite reliability dan cronbach alpha diatas 0,6 sehingga dapat dikatakan bahwa keseluruhan item pernyataan dalam setiap konstruk tersebut reliabel.

\section{Pengujian Hipotesis dan Pembahasan Analisis}

Output VPLS menunjukkan nilai $\mathrm{R}^{2}$ untuk variabel social commerce intention sebesar 0,338 . Artinya variasi perubahan variabel social commerce intention dapat dijelaskan oleh variabel satisfaction sebesar 33,8\%, sisanya dijelaskan oleh variabel lain di luar model penelitian. Nilai 
$\mathrm{R}^{2}$ untuk satisfaction sebesar 0,483, artinya variasi perubahan variabel satisfaction dapat dijelaskan oleh variabel hedonic dan utilitarian sebesar $48,3 \%$. Sedangkan besarnya nilai $\mathrm{R}^{2}$ untuk anteseden hedonic adalah sebesar 0,225. Artinya variasi perubahan variabel hedonic dapat dijelaskan oleh variabel arousal, challenge, telepresence dan time distortion sebesar 22,5\%. Nilai $\mathrm{R}^{2}$ untuk anteseden utilitarian sebesar 0,285. Artinya variasi perubahan variabel utilitarian dapat dijelaskan oleh variabel control, importance, interactivity, dan skill sebesar 28,5\%.

Selain dengan melihat nilai $\mathrm{R}^{2}$, uji model struktural ditunjukkan dengan nilai t-statistik yang dihasilkan melalui output VPLS. Nilai t-statistik harus di atas 1,64 untuk hipotesis satu arah (one-tailed) pada alpha 5\% (Hair et al., 2010).

\section{Tabel 3}

Nilai Struktural Loading dan t-statistik

\begin{tabular}{|c|c|c|c|c|c|}
\hline Hipotesis & $\begin{array}{c}\text { Nilai } \\
\text { struktural } \\
\text { loading }\end{array}$ & $\begin{array}{c}\text { Mean of } \\
\text { Subsamples }\end{array}$ & $\begin{array}{l}\text { Stdanar } \\
\text { error }\end{array}$ & t-statistik & $\begin{array}{c}\text { Keterdukungan } \\
\text { hipotesis }\end{array}$ \\
\hline H1 : AR-> HD & 0.2500 & 0.2429 & 0.0772 & 3.2368 & $\begin{array}{l}\text { Terdukung } \\
\text { (positif sig.) }\end{array}$ \\
\hline $\mathrm{H} 2: \mathrm{CH}->\mathrm{HD}$ & 0.2290 & 0.2492 & 0.0691 & 3.3162 & $\begin{array}{l}\text { Terdukung } \\
\text { (positif sig.) }\end{array}$ \\
\hline H3 : TP-> HD & -0.0280 & -0.1041 & 0.0902 & -0.3104 & $\begin{array}{c}\text { Tidak } \\
\text { Terdukung } \\
\text { (negatif tdk sig.) }\end{array}$ \\
\hline H4 : TD-> HD & 0.2550 & 0.2437 & 0.1301 & 1.9603 & $\begin{array}{l}\text { Terdukung } \\
\text { (positif sig.) }\end{array}$ \\
\hline $\begin{array}{l}\text { H5 : CTRL- } \\
>\text { UT }\end{array}$ & 0.0500 & 0.0696 & 0.0599 & 0.8347 & $\begin{array}{c}\text { Tidak } \\
\text { Terdukung } \\
\text { (positif tdk sig.) }\end{array}$ \\
\hline H6 : IM-> UT & 0.3230 & 0.3207 & 0.0817 & 3.9517 & $\begin{array}{l}\text { Terdukung } \\
\text { (positif sig.) }\end{array}$ \\
\hline H7 : IR-> UT & 0.2020 & 0.2138 & 0.0731 & 2.7635 & $\begin{array}{l}\text { Terdukung } \\
\text { (positif sig.) }\end{array}$ \\
\hline H8 : SKL-> UT & 0.1520 & 0.1508 & 0.0707 & 2.1513 & $\begin{array}{l}\text { Terdukung } \\
\text { (positif sig.) }\end{array}$ \\
\hline H9 : HD->SAT & -0.0140 & -0.0500 & 0.0389 & -0.3598 & $\begin{array}{c}\text { Tidak } \\
\text { Terdukung } \\
\text { (negatif tdk sig.) }\end{array}$ \\
\hline H10 : UT-> SAT & 0.7020 & 0.6945 & 0.0488 & 14.3924 & $\begin{array}{l}\text { Terdukung } \\
\text { (positif sig.) }\end{array}$ \\
\hline H11 : SAT->SCI & 0.5820 & 0.5818 & 0.0528 & 11.0238 & $\begin{array}{l}\text { Terdukung } \\
\text { (positif sig.) }\end{array}$ \\
\hline
\end{tabular}

Perbandingan antara t-tabel dan t-statistik pada Tabel 3 menunjukkan bahwa 8 hipotesis terdukung dengan hasil positif dan signifikan (hipotesis 1, 2, 4, 6, 7, 8, 10, dan 11) dan 3 hipotesis tidak terdukung yaitu 1 hipotesis dengan hasil positif tetapi tidak signifikan (hipotesis 5), 2 hipotesis dengan hasil negatif dan tidak signifikan (hipotesis 3 dan 9).

Hasil penelitian ini menunjukkan bahwa arousal, challenge dan time distortion berpengaruh positif terhadap pengalaman online belanja hedonic, sedangkan telepresence tidak berpengaruh. Tidak adanya pengaruh telepresence menunjukkan bahwa sebagian besar konsumen dalam social commerce yang berbelanja online melalui media sosial facebook, instagram, twitter dan path masih sadar dengan apa yang terjadi disekelilingnya dan tidak sepenuhnya terlena dalam dunia maya di media sosial saat mereka berbelanja. Penjelasan yang dimungkinkan adalah konsumen social commerce menggunakan media sosial pada waktu senggang di jam kerjanya, sehingga mereka tetap sadar dan tidak sepenuhnya terlena dalam dunia maya. Dari ketiga variabel diterima, time distortion memiliki pengaruh yang terbesar dalam pengalaman belanja online hedonic. Hasil ini menunjukkan bahwa para penjual online di media sosial harus menyediakan konten yang menarik dan menyenangkan, sehingga konsumen merasa terhanyut dalam media sosial tersebut dan menciptakan pengalaman belanja hedonic.

Importance, interactivity dan skill berpengaruh positif terhadap pengalaman belanja online utilitarian, sedangkan variabel control tidak berpengaruh. Importance memiliki pengaruh yang paling besar dan skill merupakan variabel yang terkecil pengaruhnya terhadap pengalaman belanja online utilitarian. Hasil penelitian ini menunjukkan bahwa penjual online di media sosial perlu untuk menyesuaikan konten yang ada dengan kebutuhan konsumen. Sehingga 
konsumen merasa bahwa media sosial relevan untuk pemenuhan kebutuhan hidup mereka yang pada akhirnya akan memupuk pengalaman belanja online utilitarian.

Pengalaman belanja utilitarian berpengaruh terhadap kepuasan, namun pengalaman belanja hedonic tidak berpengaruh. Halinidapatdisebabkanolehberagamnya platform media sosial yang digunakan dalam penelitian ini, yaitu Facebook, Instagram, Twitter dan Path. Masing-masing platform memiliki karakteristik tersendiri, sehingga berbeda pula persepsi konsumen terkait pengalaman yang menarik dan menyenangkan ketika berbelanja. Kepuasan berpengaruh positif terhadap niat penggunaan kembali media sosial untuk berbelanja online. Semakin konsumen merasa puas dengan sistem perdagangan online melalui media sosial, maka konsumen akan berniat menggunakan kembali media sosial untuk berbelanja.

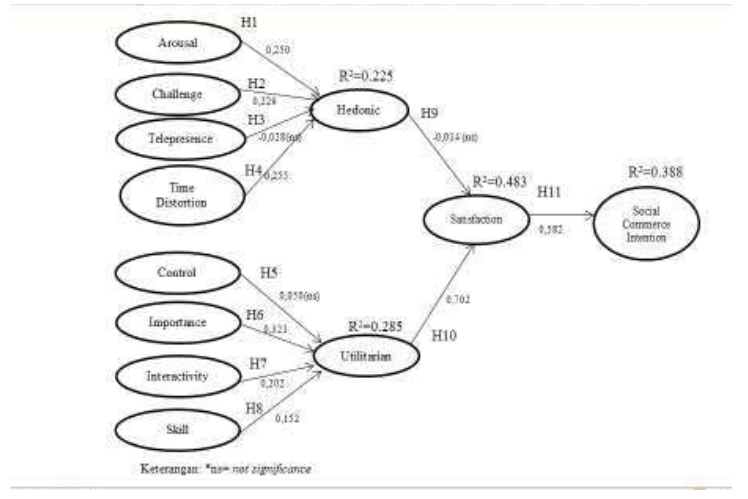

Gambar 1

Hasil Uji Model Struktural

\section{KESIMPULAN DAN SARAN}

Penelitian ini menguji hubungan antara online flow elements dan pengalaman belanja online hedonic dan utilitarian, dan pengaruh pengalaman tersebut terhadap kepuasan yang selanjutnya memengaruhi niat perilaku konsumen menggunakan media sosial Facebook, Instagram,
Twitter atau Path sebagai konteks penelitian. Penelitian ini berkontribusi pada bidang sistem informasi dan marketing dengan mengajukan dan memvalidasi model empiris penelitian mengenai bagaimana interaksi individu dengan online interface dari sistem informasi terkomputerisasi di media sosial.

Berdasarkan pengujian yang telah dilakukan menunjukkan bahwa dari 11 hipotesis yang diajukan, 8 hipotesis terdukung dan 3 hipotesis tidak terdukung. Hipotesis terdukung dengan hasil positif dan signifikan antara lain $\mathrm{H1}$,H2, H4, H6, H7, H8, H10, dan H11, sedangkan 3 hipotesis tidak terdukung yaitu 1 hipotesis dengan hasil positif tetapi tidak signifikan (H5) serta 2 hipotesis dengan hasil negatif dan tidak signifikan (H3 dan $\mathrm{H} 9)$.

Penelitian ini menggunakan platform media sosial secara umum yang banyak digunakan di Indonesia yaitu Facebook, Instagram, Twitter dan Path. Penelitian selanjutnya dapat menggunakan dua platform media sosial yang berbeda seperti Facebook dan Twitter, sehingga dapat membandingkan antara keduanya dan mengetahui apakah online flow elements berpengaruh pada pengalaman belanja online hedonic dan utilitarian yang akan memengaruhi kepuasan serta selanjutnya memengaruhi niat penggunaan kembali media sosial untuk berbelanja di masa yang akan datang.

\section{DAFTAR PUSTAKA}

Al- Kassabeh, MM., Dasgupta, S., Al-Faouri, A.H. (2011). Factors Affecting E-Service Satisfaction. Communication of the IBIMA.

Babin, B. J., W. R. Darden, dan M. Griffin. 1994. Work and/or fun: Measuring hedonic and utilitarian shopping value. Journal of Consumer Research 20 (4): 644-656. 
Bridges, E., dan R. Florsheim. 2008. Hedonic dan utilitarian shopping goals: The online experience. Journal of Business Research 61 (4): 309-314.

Childers, Terry L, Christopher L. Carr, Joann Peck, dan Stephen Carson. 2001. Hedonic dan Utilitarian Motivations for Online Retail Shopping Motivation. Journal of Retailing, 77: 511-535.

Cooper, D.R., dan Schindler, P.S., 2006. Business Research Methods. 8th Edition. McGraw-Hill, New York.

Dailey, L. 2004. Navigational Web Atmospherics: Explaining The Influence of Restrictive Navigation Cues. Journal of Business Research 57 (7): 795-803.

Fiore, A. M., H. J. Jin, dan J. Kim. 2005. For fun dan profit: Hedonic value from image interactivity dan responses toward an online store. Psychology dan Marketing 22 (8): 669-694.

Gupta, S., and H-W. Kim. 2009. Value-Driven Internet Shopping: The Mental Accounting Theory Perspective. Psychology and Marketing 27 (1): 1335.

Ghani, J. A., dan S. P. Deshpdane. 1994. Task Characteristics dan The Experience of Optimal Flow In Human Computer Interaction. Journal of Psychology 128 (4): 381-391.

Hair, J.F., Black, W.C., Babin, B.J. dan Danerson, R.E. 2010. Multivariate Data Analysis A Global Prespective. 7th Edition. Pearson Education Inc.

Hartono, Jogiyanto. Dan Abdillah, Willy. 2009. Konsep dan Aplikasi PLS untuk Penelitian Empiris. Edisi I. Yogyakarta: BPFE.

Holsapple, Clyde W. Dan Jiming Wu. 2007. User Acceptance of Virtual World: The
Hedonic Framework. The Database for Advances Information Systems 4 (38).

Heijden, Van Der Hans. 2004. User Acceptance of Hedonic Information Systems. MIS Quarterly, 4(28): 694-704.

Hoffman, D. L., dan T. P. Novak. 1996. Marketing in hypermedia computer mediated environments: Conceptual foundations. Journal of Marketing 60 (3): 50-68.

Hoffman, D. L., dan T. P. Novak. 2009. Flow online: Lessons learned dan future prospects. Journal of Interactive Marketing 23: 23-34.

Jones, M. A., K. E. Reynolds, and M. J. Arnold. 2006. Hedonic and Utilitarian Shopping Value: Investigating Differential Effects on Retail Outcomes. Journal of Business Research 59 (9): 974-981.

Kim, Sung S. Dan Jai-Yeol Son. 2009. Out of Dedication or Constraint? A Dual Model of Post-Adoption Phenomena dan Its Empirical Test in The Context of Online Services. MIS Quarterly, Vol 33 (1): 4970.

Koufaris, M. 2002. Applying The Technology Acceptance Model And Flow Theory To Online Consumer Behavior. Information Systems Research 13 (2): 205-223.

Lau, E. K. 2012. Adoption of online group buying. European Journal of Management 11 (4): 54-60.

Lee, S. M., and L. Chen. 2010. The impact of flow on online consumer behavior. Journal of Computer Information Systems 50 (4): $1-10$.

Liang, T.P., Y.T. Ho, Y.W. Li, dan E. Turban. 2011. What Drives Social Commerce: The Role of Social Support dan Relationship Quality. International Journal of Electronic Commerce 6 (2): 69-90. 
Liang, Ting-Peng dan Efraim Turban. 2011. Intoduction to the Special Issue Social Commerce: A Research Framework for Social Commerce.

Lim, W. M. 2013. Toward A Theory of Online Buyer Behavior Using Structural Equation Modeling. Modern Applied Science 7 (10): 34-41.

Lim, Weng Marc. 2014. Understdaning the Influence of Online Flow Elements on Hedonic dan Utilitarian Online Shopping Experience: A Case of Online Group Buying. Journal of Information Systems, Vol.28 (2): 287-306.

Lim, W. M., and D. H. Ting. 2012a. E-shopping: An analysis of the technology acceptance model. Modern Applied Science 6 (4): 49-62.

Lim, W. M., and D. H. Ting. 2012b. E-shopping: An analysis of the uses and gratifications theory. Modern Applied Science 6 (5): 48-63.

McQuarrie, E. F., and J. M. Munson. 1992. A revised product involvement inventory: Improved usability and validity. Advances in Consumer Research 19: 108-115.

Nah, Fiona Ful-Hooh, Brenda E., dan David DeWester. 2011. Enhancing Brdan Equity Through Flow dan Telepresence: A Comparison of 2D dan 3D Virtual Worlds. MIS Quarterly, 3 (35): 731-747.

Novak, T. P., D. L. Hoffman, and Y.-F. Yung. 2000. Measuring The Customer Experience in Online Environments: A Structural Modeling Approach. Marketing Science 19: $22-42$.

Okada, E. M. 2005. Justification Effects on Consumer Choice of Hedonic And Utilitarian Goods. Journal of Marketing Research 42 (1): 43-53.
O’Shaughnessy, J., dan N. J. O'Shaughnessy. 2002. Marketing, The Consumer Society dan Hedonism. European Journal of Marketing 36 (5): 524-547.

Richard, M.-O., dan R. Chandra. 2005. A model of consumer web navigational behavior: Conceptual development and application. Journal of Business Research 58 (8): 1019-1029.

Sagala, G. Hafiz dan Sumiyana. 2014. The Intersection Of Hedonic And Utilitarian Values In The Success Model Of Information System: A Study On Social Media. Simposium Nasional Akuntansi XVII.

Scarpi, D. 2012. Work dan fun on the Internet: The effects of utilitarianism dan hedonism online. Journal of Interactive Marketing 26 (1): 53-67.

Sekaran, Uma. 2003. Research Methods for Business 4th Edition. John Willey dan Sons Inc.

Shank, P. 2011. The Online Learning Idea Book: Proven Ways to Enhance TechnologyBased and Blended Learning. San Francisco, CA: John Wiley \& Sons.

Shih, C. 1998. Conceptualizing Consumer Experiences in Cyberspace. European Journal of Marketing 32 (7): 655-663.

Sledgianowski, D., dan S. Kulviwat. 2009. Using Social Network Sites: The Effects of Playfulness, Critical Mass and Trust In A Hedonic Context. Journal of Computer Information Systems 49 (4): 74-83.

Smith, D. N., dan K. Sivakumar. 2004. Flow and Internet Shopping Behavior: A Conceptual Model and Research Propositions. Journal of Business Research 57: 1199-1208. 
Straub, D., dan R. T. Watson. 2001. Transformational Issues in Researching IS And Net-Enabled Organizations. Information Systems Research 12 (4): 337-345.

Veenhoven, R. 2003. Hedonism dan Happiness. Journal of Happiness Studies 4: 437457.

Wang, Zhihuan dan Helena Scheepers. 2012. Understdaning the Intrinsic Motivation of User Acceptance of Hedonic Information Systems: Toward Unified Research Model. Journal of The Association for Information Systems, (30) Article 17: 255-274.

Wang, Yi-Shun. 2007. Assessing E-commerce Systems Sucess: A Respesification dan Validation of the DeLone dan McLean Model of IS Sucess. Information Systems Journal, 18: 529-557.

Ward, J. C., and J. W. Barnes. 2001. Control And Affect: The Influence of Feeling in Control of The Retail Environment on Affect, Involvement, Attitude, And Behavior. Journal of Business Research 54 (2):139-144.
Widiartanto, Yoga Hastyadi. 2016. "2016, Pengguna Internet di Indonesia Capai 132 Juta". Diambil dari : http://tekno.kompas. com/read/2016/10/24/15064727/2016. pengguna.internet.di.indonesia. capai.132.juta.

Wolfinbarger, M., dan M. C. Gilly. 2001. Shopping Online for Freedom, Control dan Fun. California Management Review 43 (2): 34-55.

Zhang, X.,. R.V.R.S. Prybuyok dan Pavur. 2009. A Model of the Relationship among Consumert Trust, Web Desaogn dan A Assui. 2009, Vol 21 dari 3.

Zhang, H., Y. Lu, S. Gupta dan L. Zhao. 2014. What Motivates Customers to Participate in Social Commerce? The Impact of Technological Environments dan Virtual Customer Experience. Information \& Management 51: 1017-1030.

Zhou, Zhongyun Phil, Y. Fang, Douglas R Vogel, Xiao-Ling Jin dan Xi Zhang. 2012. Attracted to or Locked In? Predicting Continuance Intention in Social Virtual World Services. Journal of Management Information Systems, 29: 273-305. 